\title{
The Emergence of Time in Latin Literature
}

\author{
Patrice F Dassonville* \\ Department of physics and chemistry, University of National High School of Niamey, France
}

Received: 海 August 15, 2018; Published: 眥 August 24, 2018

*Corresponding author: Patrice F Dassonville, Department of physics and chemistry, University of National High School of Niamey, France

\section{Introduction}

During the thirteenth century BC, the Lydians, who were Greeks of Asia Minor, were compelled by famine to emigrate to what is now Tuscany, where they established a new civilization with the native population. According to the Greek historian Herodotus (484425), these were the Etruscans. (Book I, 94) [1]. Their alphabet derived from Greek in the eighth century BC and it gave the Roman alphabet in the seventh century BC (Frédérix, $C h I$ ) [2]. In order to situate themselves in relation to what they observed, the Romans unknowingly started conceptualizing some current phenomena and some familiar events. In this way and step by step, they enriched their language by introducing new concepts. The Latin literature allows one to observe the emergence of temporality in the Roman civilization, as well as to follow its gradual development.

\section{The Calends}

The Calends was the first day of the lunar month. We find Calendae in Cicero (106-43) and Calendae Martiae (the Calends of March) in Horace (65-8 AD). It was unknown to the Greeks, hence the famous proverb in Suetonius (c.70-c.122): ad calendas graecas solvere (pay at the Greek Calends), which meant never (Gaffiot) [3]. The Consul Ausonius, in The other prayer to the calends of January (379 AD), was the first in Rome to associate the regular advent of seasons with annus (Quet p. 553) [4]. Indeed, before Ausonius, the year had erratic values. In Valerius Martialis (first century BC) we find intra septimas calendas for before six months [3]. The month was the lunar month. The month of January was dedicated to Janus : the very ancient God with two faces opened and closed the year. For the Senufo of the Ivory Coast, the Janus type of sculpture represents time passing; one face is looking at the past while the other is looking toward the future.

\section{The Consular Year}

In Rome, there was no reference event, so for each year the text began by : Under the consulate of.

For example, wines were dated using the names of the two consuls who held office that year. Their names were inscribed on the amphorae ; it was called the consular year [2]. The Latin annalist Tacit (c.55-c.120) envied these great historians who described such major events. His Annals (from Latin annales) are an annual narrative of the facts according to the consular chronology : facts, minor at first view, but which often produce great events (Book IV, Ch. XXXII, 2) [5]. The narration of the events was drafted by the magistrates and recorded in the acta senatus, the Journal of Acts. [2] The Romans engraved their laws on stone tablets and their archives on copper tablets, in order to preserve them inside the Capitol. Tacit explained how the Romans came to draft an infinite number of laws, and he emphasized the diversity of the laws (Book III, Ch. XXV, 2) [5]. The Sicilian Diodorus (c.90-30) confided: We looked carefully at the records held by the Romans for so long, in order to bring to light the history of this huge empire [6].

\section{The Diachrony of Terminology}

The diachrony, from Greek dia (through) and khronos (time), describes changes with time, not changes because of time. The following list, gathered in Latin literature thanks to F. Gaffiot [3], allows dating approximately each word, formalizing its use by the Romans, and observing the gradual enrichment of its meaning. In Plautus (254-184) duro means be patient. In varro (116-27) morax means which delays; annus means year and temporalis means which designates time. In Cicero (106-41) we find anno for each year; ad annum for within a year; ad extremum tempus diei for until the last moment of the day; ad hoc tempus for at this moment; cras for tomorrow; ex eo tempore for from that moment on; in reliquum tempus means for the remaining time; longiquitas for duration and long period; longo post tempore for long after; parva mora for short notice; per idem tempus for at the same time; tempestas for weather, season, time; tempori for right on time; tempus anni for season; tempus est for it is time; temporalis for temporary. In Caesar (101-44) in singula dieu tempora means for each moment of the day; nocturna tempora means night time; annum for one year; pro tempore means depending on time; spatium means duration. 
Lucretius (c.96-55) mentions the revolutions of the sun (Song V, 931), time which rolls out (Song V, 1276) [7], and we find durabilis for lasting; duro for to last; in parvo post tempore for shortley afterwards; volventibus annis for the years roll out. Virgil (c.70-c.19) refers to volvenda dies: the rolling out of the days; he uses ex longo for since long ago; longaevus for old age; longo post tempore for long after; and annus for season. In Horace (65-8 BC) horae momento means a duration of one hour. Augustus (63 BC-14 AD) uses super for a while. In Titus Livius (c.59 BC-17 AD) we have locus for moment; longiquitas for long period; momentum for duration, moment; spatium tempus for space of time. For Seneca (c.4 BC- 65) crastinum means the day after; ex tempore means day by day, out of time; temporalis means temporary. Statius (c.45-96) uses crastinus for forthcoming, futur. Tacitus (c.55-c.120) uses durabilis for lasting. In Pliny (61-c.114) we find in crastinum for until tomorrow; extendo for extend (a duration); inter moras for pending; longinquum for long time; luna for month; magnitudo for duration; per tempus for on time; and stato tempore for at a fixed time. Tertulliannus (c.155-c.222) uses temporalitas for limited duration.

\section{Definitions}

What the Romans did with these ideas gives us the ability to draft basic definitions. It must be emphasized that using the words time and duration is not allowed as far as these words are not defined. We have to do with the little that is available.

According to Valerius Martialis: The month is a concept which corresponds to what separates two successive calends. Of course, the value of the month is more reliable when referring to the lunar month. The absence of definitions explains why in certain countries such as Mesopotamia, Egypt, Greece, in Rome before Caesar, the year have had erratic values. The definition according to the Consul Ausonius would be: The year is a concept which corresponds to the return of the seasons. (for example, the return of spring).

\section{Conclusion}

The Romans become aware of temporality late compared to many other cultures. For example, the Sumerians invented the lunar month over 4500 years ago. Fortunately, the Latin literature provides a very interesting view of the development of time in Roman culture; like an irrepressible need to situate events and phenomena. However only very few offered the opportunity of defining more concepts of temporality, they show us the way to do it.

\section{References}

1. Gallimard (1964) Herodotus : The Inquiry L'Enquête - translated from Greek into French by A Barguet.

2. Albin Michel (1969) Frédérix P : Rome, History of the Eternal City Rome, Histoire de la Ville Éternelle.

3. Hachette (2000) Gaffiot F : Dictionnaire Latin-Français.

4. Quet M H (2006) The Crisis of the Roman Empire from Marcus Aurelius to Constantinus La Crise de L'Empire Romain de Marc Aurèle à Constantin. Presse de l'Université Paris Sorbonne.

5. Gallimard (1993) Tacit : Annals (Édn) de Pierre Grimal.

6. Diodorus: preface of The Historical Library. La Bibliothèque Historique. Site of Ph Remacle.

7. Gallimard (2010) Lucretius: The nature of things De rerum naturae. Translated in French by J Pigeaud.

8. Dassonville P (2017) This topic has been developed in detail in: The Invention of Time and Space.

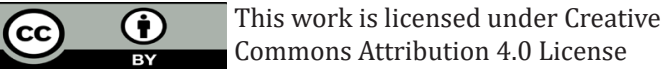

To Submit Your Article Click Here: Submit Article

DOI: 10.32474/PRJFGS.2018.02.000128

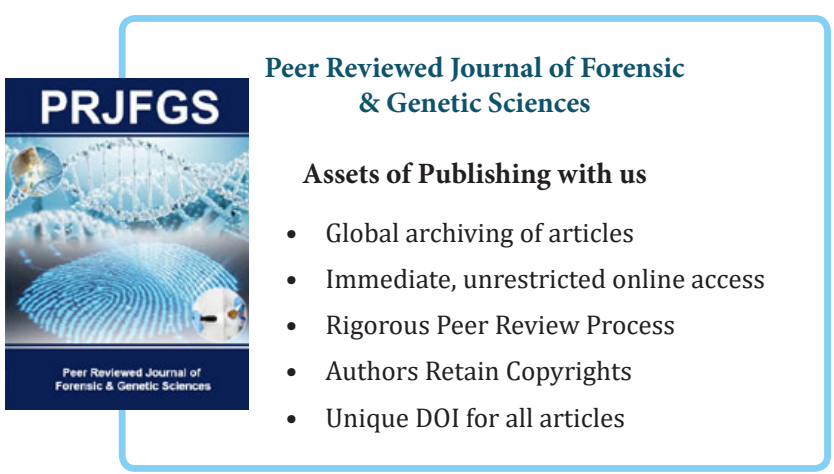

